Article

\title{
Discordant Liver Fibrosis Predictors in Virologically Suppressed People Living with HIV without Hepatitis Virus Infection
}

\author{
Barbara Rossetti ${ }^{1, *}$, Valentina Borgo ${ }^{1,2}$, Arianna Emiliozzi ${ }^{2}$, Marta Colaneri ${ }^{3}{ }^{\circ}$, Giacomo Zanelli ${ }^{1,2}$, \\ Miriana d'Alessandro ${ }^{4}\left(\mathbb{D}\right.$, Davide Motta ${ }^{5}$, Laura Maiocchi ${ }^{3}$, Francesca Montagnani ${ }^{1,2}{ }^{(D}$, Maria Cristina Moioli ${ }^{5}$, \\ Chiara Baiguera ${ }^{5}$, Margherita Sambo ${ }^{3}$, Teresa Chiara Pieri ${ }^{3}$, Pietro Valsecchi ${ }^{3}$, Raffaele Bruno ${ }^{3}{ }^{1}$, \\ Massimo Puoti ${ }^{5}$ and Massimiliano Fabbiani ${ }^{1}$ (1)
}

1 Infectious and Tropical Diseases Unit, Siena University Hospital, 53100 Siena, Italy; valentina.borgo1989@gmail.com (V.B.); giacomo.zanelli1971@gmail.com (G.Z.); francesca.montagnani@unisi.it (F.M.); massimiliano.fabbiani@gmail.com (M.F.)

2 Department of Medical Biotechnologies, University of Siena, 53100 Siena, Italy; ariannaemiliozzi@gmail.com

3 Infectious Diseases I Unit, I.R.C.C.S. Policlinico San Matteo Foundation, 27100 Pavia, Italy; marta.colaneri@gmail.com (M.C.); L.Maiocchi@smatteo.pv.it (L.M.); sambomargherita@gmail.com (M.S.); teresachiara.pieri01@universitadipavia.it (T.C.P.); pietro.valsecchi01@universitadipavia.it (P.V.); raffaele.bruno@unipv.it (R.B.)

4 Respiratory Diseases and Lung Transplant Unit, Department of Medical and Surgical Sciences and Neurosciences, University of Siena, 53100 Siena, Italy; dalessandro.miriana@gmail.com

check for updates

Citation: Rossetti, B.; Borgo, V.; Emiliozzi, A.; Colaneri, M.; Zanelli, G.; d'Alessandro, M.; Motta, D.; Maiocchi, L.; Montagnani, F.; Moioli, M.C.; et al. Discordant Liver Fibrosis Predictors in Virologically Suppressed People Living with HIV without Hepatitis Virus Infection. Diagnostics 2022, 12, 14. https:// doi.org/10.3390/diagnostics12010014

Academic Editors: Carmen de Mendoza and Laurent Bélec

Received: 11 November 2021 Accepted: 17 December 2021 Published: 22 December 2021

Publisher's Note: MDPI stays neutral with regard to jurisdictional claims in published maps and institutional affiliations.

Copyright: (C) 2021 by the authors. Licensee MDPI, Basel, Switzerland. This article is an open access article distributed under the terms and conditions of the Creative Commons Attribution (CC BY) license (https:// creativecommons.org/licenses/by/ $4.0 /)$.
5 Infectious Diseases Unit, Niguarda Hospital, 20162 Milan, Italy; davide.motta@ospedaleniguarda.it (D.M.); mariacristina.moioli@ospedaleniguarda.it (M.C.M.); chiara.baiguera@ospedaleniguarda.it (C.B.); massimo.puoti@ospedaleniguarda.it (M.P.)

* Correspondence: brossetti1982@gmail.com; Tel.: +39-3201437658; Fax: +39-0577586580

\begin{abstract}
Severe liver fibrosis (LF) is associated with poor long-term liver-related outcomes in people living with HIV (PLWH). The study aimed to explore the prevalence and predictors of LF and the concordance between different non-invasive methods for the estimation of LF in HIV-infected individuals without hepatitis virus infection. We enrolled PLWH with HIV-1-RNA $<50$ copies $/ \mathrm{mL}$ for $>12$ months, excluding individuals with viral hepatitis. LF was assessed by transient elastography (TE) (significant $>6.65 \mathrm{kPa}$ ), fibrosis-4 (FIB-4) (significant $>2.67$ ), and AST-to-platelet ratio index (APRI) (significant $>1.5$ ). We included 234 individuals ( $67 \%$ males, median age 49 years, median time from HIV diagnosis 11 years, $38 \%$ treated with integrase strand transfer inhibitors). In terms of the TE, $13 \%$ had $\geq$ F2 stage; FIB- 4 score was $>1.5$ in 7\%; and APRI $>0.5$ in $4 \%$. Higher body mass index, diabetes mellitus, detectable baseline HIV-1 RNA and longer atazanavir exposure were associated with higher liver stiffness as per TE. Predictors of higher APRI score were CDC C stage and longer exposure to tenofovir alafenamide, while $\mathrm{HBcAb}$ positivity and longer exposure to tenofovir alafenamide were associated to higher FIB-4 scores. Qualitative agreement was poor between FIB-4/TE and between APRI/TE by non-parametric Spearman correlation and kappa statistic. In our study, in the group of PLWH without viral hepatitis, different non-invasive methods were discordant in predicting liver fibrosis.
\end{abstract}

Keywords: liver fibrosis; HIV; ART

\section{Introduction}

Human immunodeficiency virus (HIV) infection is one of the most serious public health challenges, affecting approximately 37.6 million people across the globe in 2020, of whom 34 million are adults [1]. As a result of remarkable advances in scientific understanding of HIV and its prevention and treatment, after the introduction of highly active antiretroviral treatment (HAART) back in 1996, the leading causes of morbidity and mortality among people living with HIV (PLWH) in high-income countries have switched 
from opportunistic infections and AIDS-related neoplasms to non-AIDS related events, especially cardiovascular and liver disorders [2-5]. Prevalence of liver involvement in PLWH ranges from 4 to $18 \%$ according to different studies, while up to $18 \%$ of deaths were liver-related in some European real-life cohorts [6-11].

Severe liver fibrosis is associated with poor long-term liver-related outcomes and mortality, and PLWH are at higher risk of multifactorial liver injuries than people without HIV [12-18].

Several studies have confirmed the possible causes contributing to the progression of liver fibrosis in PLWH, in particular, age, coinfections with viral hepatitis and alcohol abuse [19-24]. On the other hand, the potential effect of body mass index and the presence of hypertriglyceridemia or diabetes mellitus are debated and inconclusive [22,25].

The cornerstone finding in all recent studies is the association between HIV per se and low $\mathrm{CD}^{+}$cells count with liver fibrosis [26-29]. HIV primarily infects liver macrophages, but also hepatocytes and hepatic stellate cells, leading to fibrosis by inflammation and necrosis of hepatocyte cells, increased intra-hepatic expression of collagen and enhanced expression of the transforming growth factors [27,28]. Furthermore, HIV directly causes endoplasmic reticulum stress, mitochondrial toxicity and increased oxidative stress, with decreased beta-oxidation of fatty acids and the accumulation of fat in the liver. Indeed, it may also cause a gut barrier dysfunction, leading to high amounts of circulating lipopolysaccharides, responsible of augmented insulin resistance, overproduction of tumor necrosis factor-alpha, triglyceride accumulation, inflammation, non-alcoholic steatohepatitis and lastly liver fibrosis [30-35].

Although the START trial showed that the effective control of HIV replication with early ART initiation seems to be protective for liver fibrosis progression, the hepatotoxicity of antiretroviral drugs has been debated and many controversies still exist. Several studies have shown a significant liver injury after treatment with some nucleos $(\mathrm{t})$ ide reverse transcriptase inhibitors (NRTIs), mainly didanosine (DDI) and azidothymidine (AZT) [36-39]. On the contrary, integrase strand transfer inhibitors (INSTIs) and non-nucleoside reverse transcriptase inhibitors (NNRTIs), with the exception of nevirapine (NVP), are proven to be safe for liver health [40-43]. Even though protease inhibitors (PIs) cause insulin resistance and lipodystrophy, data from studies regarding hepatotoxicity of this drug class are controversial [44-46].

Different non-invasive methods are nowadays available in order to assess the risk of liver damage, mainly including serological panels and radiological test, with transient elastography (TE) being the most extensively and routinely used $[47,48]$.

The majority of these methods have been validated in specific subset of patients. AST to Platelet Ratio Index (APRI) score has been investigated mainly in HCV-infected or HIV-HCV coinfected individuals and in those affected by alcohol-related disease, while fibrosis-4 (FIB-4) score in HCV-infected individuals, in those affected by non-alcoholic fatty liver disease (NAFLD) and among PLWH coinfected with HCV [49-53].

On these bases, the primary outcome of our study was to evaluate the prevalence of significant liver fibrosis in HIV-infected virologically suppressed individuals without hepatitis virus infection by non-invasive methods. Secondary outcomes included the evaluation of the concordance of different non-invasive methods for the estimation of liver fibrosis and the identification of predictors of advanced liver fibrosis in a real-life multicenter cohort.

\section{Materials and Methods}

\subsection{Study Design and Population}

We performed a multicenter retrospective cross-sectional study including PLWH who consecutively underwent liver fibrosis assessment by transient elastography (TE) at three HIV referral centers in Northern and Central Italy (Milan, Pavia and Siena) from January 2014 and February 2020. 
We recruited PLWH aged $\geq 18$ years that were HIV-1-infected and treated with antiretroviral drugs from at least 18 months and with virological suppression (defined as HIV-1 RNA < 50 copies/mL) from at least 12 months (isolated blips were allowed), with full accessibility to past medical records.

Exclusion criteria were as follows: (i) detectable HCV-RNA or hepatitis B surface antigen positivity; (ii) previous treatment for HCV infection; (iii) significant alcohol intake, defined as daily consumption exceeding $30 \mathrm{~g}$ for males and $20 \mathrm{~g}$ for females; (iv) evidence of other liver diseases; (v) history of hepatocellular carcinoma or liver transplantation or liver cirrhosis; (vi) contraindications to TE examination (pregnancy, pacemaker insertion); (vii) failure or unreliable measurement of TE examination.

Participants underwent assessment of liver fibrosis by TE and concomitantly by FIB- 4 index and APRI score.

Data collection was approved by the local ethics committees and informed consent was obtained from all patients before participation. The study was carried out in accordance with the ethical principles of the Declaration of Helsinki and with the Good Clinical Practice guidelines of the International Conference on Harmonization.

\subsection{Study Procedures}

At the time of enrollment, clinical and anthropometric data were collected including demographic characteristics, HIV and medication history and body mass index (BMI). Moreover, a $12 \mathrm{~h}$ overnight fasting blood sample to determine liver biochemistries, lipid profile, hematological and immuno-virological parameters was drawn within 1 month from the TE examination.

Liver fibrosis was assessed by transient elastography (FibroScan, Echosens, Paris, France) on $4 \mathrm{~h}$ fasting individuals by maximum two experienced operators at each site (>100 examinations before the study) [47,54]. The standard M probe was used in all individuals and the XL probe was used in case of failure with M probe or in case of skin to liver distance $>2.5 \mathrm{~cm}$, as suggested by the manufacturer [47]. Liver stiffness measurement was expressed in kilopascal $(\mathrm{kPa})$ and calculated as the median value of 10 successful acquisitions, defined by a success rate of at least $60 \%$, and by an interquartile range lower than $30 \%$, as previously described and as suggested by the manufacturing company [47].

Non-invasive serum biomarker liver fibrosis scores (FIB-4 index and APRI scores) were calculated as close as possible to the date of TE [48]. The formula used to calculate APRI score was: (AST/upper limit of normal considered as $40 \mathrm{IU} / \mathrm{L}$ )/platelet count (expressed as platelets $\left.\times 10^{9} / \mathrm{L}\right) \times 100$. FIB- 4 index was calculated as: age [years] $\times$ AST [IU $\left./ \mathrm{L}\right] /$ platelet count [expressed as platelets $\left.\times 10^{9} / \mathrm{L}\right] \times\left(\mathrm{ALT}^{1 / 2}[\mathrm{IU} / \mathrm{L}]\right)[49,50]$.

According to the previous data from literature, we considered consistent with significant liver stiffness measurement values at TE $>6.65 \mathrm{kPa}$ (stage F0-F1: 0-6.65 kPa; F2: >6.65-7.9 kPa; F3: >7.9-9.6 kPa; F4: >9.6 kPa), FIB-4 score > 2.67 and APRI score $>1.5$. FIB-4 scores $<1.30$ and APRI score $<0.5$ were considered consistent with low-grade or absent liver fibrosis [51-54].

Type 2 diabetes mellitus was defined as a fasting blood glucose level $\geq 126 \mathrm{mg} / \mathrm{dL}$ or as treatment with glucose-lowering drugs. According to WHO standards, cut-offs for BMI categories were defined as follows: underweight $<18.5 \mathrm{~kg} / \mathrm{m}^{2}$, normal $18.5-24.9 \mathrm{~kg} / \mathrm{m}^{2}$, overweight $>25 \mathrm{~kg} / \mathrm{m}^{2}$, and obese $\geq 30 \mathrm{~kg} / \mathrm{m}^{2}$. Hyperlipidemia was defined as low-density lipoprotein (LDL) cholesterol levels $\geq 130 \mathrm{mg} / \mathrm{dL}$ and/or total cholesterol $\geq 200 \mathrm{mg} / \mathrm{dL}$ and/or tryglicerides $\geq 150 \mathrm{mg} / \mathrm{dL}$ and/or treatment with lipid-lowering drugs.

CD4 cells count was determined as follows: $50 \mu \mathrm{L}$ of EDTA-blood cells were processed by flow cytometry using a diagnostic panel of monoclonal antibodies (BD Multitest ${ }^{\mathrm{TM}}$ 6-color TBNK, San Jose, CA, USA), including FITC-labeled CD3, PE-labeled CD16 and CD56, PerCPCy5.5-labeled CD45, PECy7-labeled CD4, APC-labeled CD19, and APCCy7-labeled CD8, according to the manufacturer's instructions. At least 300,000 events were collected for each sample. Data were analyzed using FACSCanto II flow cytometry and CANTO software (BD-Biosciences San Jose, CA, USA). 


\subsection{Statistical Analysis}

Continuous variables were summarized as median \pm interquartile range (IQR), and categorical variables as frequency and percentage. Predictors of significant liver fibrosis were investigated by unadjusted and adjusted regression models and reported as adjusted odds ratios (aOR) with 95\% confidence interval (CI). All adjusted regression models included covariates that were determined a priori to be clinically important, according to previous literature data, or those with $p$-value $<0.05$ in univariable analysis.

The correlation between TE/FIB- 4 and TE/APRI was evaluated by non-parametric Spearman correlation and kappa statistic.

Statistical analyses were performed using the SPSS Software, version 23.0 (SPSS Inc., Chicago, IL, USA).

\section{Results}

\subsection{Study Population}

We enrolled 234 PLWH who fulfilled the inclusion and exclusion criteria. Table 1 reports the baseline characteristics of the whole population.

Table 1. Baseline characteristics $(n=234)$.

\begin{tabular}{|c|c|}
\hline Age, Years ${ }^{a}$ & $49(42-56)$ \\
\hline Gender, male ${ }^{b}$ & $158(67.5)$ \\
\hline \multicolumn{2}{|l|}{ Ethnicity $\mathrm{b}$} \\
\hline Caucasian & $209(89.3)$ \\
\hline African & $18(7.7)$ \\
\hline Asian & $5(2.1)$ \\
\hline Hispanic & $2(0.9)$ \\
\hline \multicolumn{2}{|l|}{ Risk factors for HIV ${ }^{b}$} \\
\hline Sexual intercourses & $166(71.0)$ \\
\hline Males who have sex with males & $69(29.5)$ \\
\hline Heterosexuals & $97(41.5)$ \\
\hline Injecting drug users & $42(17.9)$ \\
\hline Other/unknown & $26(11.1)$ \\
\hline Time from HIV diagnosis, years ${ }^{a}$ & $11(5-17)$ \\
\hline Nadir CD4 cells count, cell/Ml a $(n=211)$ & $255(127-485)$ \\
\hline Nadir CD4/CD8 ${ }^{a}(n=106)$ & $0.38(0.18-0.67)$ \\
\hline Zenith HIV-1 RNA, $\log _{10} \mathrm{cp} / \mathrm{mL}^{\mathrm{a}}(n=141)$ & $4.84(4.33-5.43)$ \\
\hline CDC stage $C^{b}(n=231)$ & $60(25.7)$ \\
\hline Baseline CD4 cells count, cell $/ \mu \mathrm{L}^{\text {a }}(n=233)$ & $670(515-853)$ \\
\hline Baseline CD4/CD8 ${ }^{a}(n=228)$ & $0.9(0.6-1.4)$ \\
\hline Baseline HIV-1 RNA $<50 \mathrm{cp} / \mathrm{mL}^{\text {but detectable }}{ }^{\text {a }}$ & $67(28.6)$ \\
\hline \multicolumn{2}{|l|}{ Current antiretroviral therapy $\mathrm{b}$} \\
\hline 3 Drug regimens & $186(79.1)$ \\
\hline$<3$ Drug regimens & $45(19.6)$ \\
\hline$>3$ Drug regimens & $3(1.3)$ \\
\hline \multicolumn{2}{|l|}{ Previous antiretroviral drugs used ${ }^{b}$} \\
\hline NRTI & $233(99.6)$ \\
\hline PI or bPI & $153(65.4)$ \\
\hline NNRTI & $137(58.5)$ \\
\hline INSTI & $106(45.3)$ \\
\hline MVC & $9(3.8)$ \\
\hline T20 & $6(2.6)$ \\
\hline \multicolumn{2}{|l|}{ Current antiretroviral regimens $\mathrm{b}$} \\
\hline INSTI-based & $88(37.6)$ \\
\hline NNRTI-based & $84(35.9)$ \\
\hline PI or bPI-based & $49(20.9)$ \\
\hline Other & $13(5.5)$ \\
\hline $\mathrm{HBcAb}$ positivity $\mathrm{b}$ & $62(26.5)$ \\
\hline Alcohol user ${ }^{b}$ & $70(29.9)$ \\
\hline
\end{tabular}


Table 1. Cont.

\begin{tabular}{|c|c|}
\hline Age, Years ${ }^{a}$ & $49(42-56)$ \\
\hline Smokers ${ }^{b}$ & $85(36.3)$ \\
\hline Diabetes mellitus ${ }^{b}$ & $17(7.3)$ \\
\hline Glycemia, mg/dL a $(n=228)$ & $88(82.2-96.7)$ \\
\hline Dyslipidemia ${ }^{b}$ & $164(70.0)$ \\
\hline Total cholesterol, $\mathrm{mg} / \mathrm{dL}^{\mathrm{a}}(n=230)$ & $201(180-227)$ \\
\hline LDL cholesterol, $\mathrm{mg} / \mathrm{dL}^{\mathrm{a}}(n=191)$ & $130(108-154)$ \\
\hline Triglycerides, $\mathrm{mg} / \mathrm{dL}^{\mathrm{a}}(n=230)$ & $113(80-165)$ \\
\hline Aspartate aminotransferase, $\mathrm{IU} / \mathrm{mL}^{\mathrm{a}}(n=230)$ & $21(17-26)$ \\
\hline Alanine aminotransferase, $\mathrm{IU} / \mathrm{mL}^{\mathrm{a}}(n=230)$ & $21(15-30)$ \\
\hline Platelets, $10^{3} / \mathrm{mmc}^{\text {a }}(n=230)$ & $229(197-268)$ \\
\hline Total bilirubin, $\mathrm{mg} / \mathrm{dL}^{\mathrm{a}}(n=214)$ & $0.4(0.3-0.6)$ \\
\hline Gamma-glutamyl transferase, $\mathrm{U} / \mathrm{L}^{\mathrm{a}}(n=231)$ & $24(16-40)$ \\
\hline $\mathrm{BMI}^{\mathrm{a}}(n=233)$ & $23.7(21.4-26.5)$ \\
\hline Underweight $^{\mathrm{b}}<18.5 \mathrm{~kg} / \mathrm{m}^{2}$ & $13(5.6)$ \\
\hline Normal weight ${ }^{b} 18.5-24.9 \mathrm{~kg} / \mathrm{m}^{2}$ & $137(58.5)$ \\
\hline Overweight $^{b}>25 \mathrm{~kg} / \mathrm{m}^{2}$ & $68(29.1)$ \\
\hline Obesity ${ }^{b} \geq 30 \mathrm{~kg} / \mathrm{m}^{2}$ & $15(6.4)$ \\
\hline Median stiffness at TE, in $\mathrm{kPa}^{\text {a }}$ & $4.6(4.0-5.8)$ \\
\hline \multicolumn{2}{|l|}{ Fibrosis stage at $\mathrm{TE}$} \\
\hline F0-F1 & $203(86.8)$ \\
\hline F2 & $24(10.2)$ \\
\hline F3 & $6(2.6)$ \\
\hline $\mathrm{F} 4$ & $1(0.4)$ \\
\hline Median APRI score ${ }^{\text {a }}(n=229)$ & $0.25(0.18-0.31)$ \\
\hline $\mathrm{APRI}<0.5^{\mathrm{b}}$ & $220(96.1)$ \\
\hline $0.5 \leq \mathrm{APRI}<1.5^{\mathrm{b}}$ & $8(3.5)$ \\
\hline $\mathrm{APRI} \geq 1.5^{\mathrm{b}}$ & $1(0.4)$ \\
\hline Median FIB-4 score ${ }^{a}(n=228)$ & $0.92(0.71-1.20)$ \\
\hline FIB- $4<1.3^{\mathrm{b}}$ & $211(92.5)$ \\
\hline $1.3 \leq$ FIB- $4<2.67^{b}$ & $14(6.1)$ \\
\hline FIB- $4 \geq 2.67^{b}$ & $3(1.3)$ \\
\hline
\end{tabular}

a Median (IQR); ${ }^{\mathrm{b}} \mathrm{n}(\%)$; unless otherwise indicated. Table 1 legend: APRI, AST-to-platelet ratio index; BMI, body mass index; CDC, United States Centers for Disease Control and Prevention; FIB-4, fibrosis-4 score; HIV, human immunodeficiency virus; INSTI, integrase strand transfer inhibitor; LDL cholesterol, low-density lipoprotein; MVC, maraviroc; NNRTI, non-nucleoside reverse-transcriptase inhibitor; NRTI, nucleos(t)ide reverse-transcriptase inhibitor; PI, protease inhibitor; bPI, boosted protease inhibitor; T20, enfuvirtide; TE, transient elastography.

Caucasian ethnicity, male gender and sexual intercourse as a risk factor prevailed, respectively, in $89.3 \%, 67.5 \%$, and $71 \%$ of cases. A quarter of the whole population reported a CDC stage $C$ and a nadir CD4 cells count $<200$ cell $/ \mu \mathrm{L}$. Among 186 individuals on threedrug regimens, $70(37.6 \%)$ were treated with INSTIs, $32(17.2 \%)$ with PIs or b-PIs, $82(44.1 \%)$ with NNRTIs and $2(1.1 \%)$ with other regimens. NRTI backbones were tenofovir disoproxil fumarate (TDF) or tenofovir alafenamide (TAF) + emtricitabine (FTC) in $132(70.9 \%)$ and abacavir (ABC) + lamivudine (3TC) in $54(29.1 \%)$. Among 38 participants on $<3$-drug regimens, $15(39.5 \%)$ were treated with dolutegravir (DTG) +3 TC, $9(23.7 \%)$ with boosted (b)-PIs monotherapy, $6(15.8 \%)$ with boosted-PIs + 3TC, 5 (13.1\%) with b-PIs + INSTIs, and $3(7.9 \%)$ with other combinations. Three individuals were treated with 2NRTIs + INSTI + bPI.

According to previous antiretroviral drug exposure, almost all the population was exposed to NRTIs and more than $50 \%$ to NNRTIs and PIs during a median HIV seropositivity time of 11 (IQR 5-17) years.

A previous $\mathrm{HBV}$ exposure ( $\mathrm{HBcAb}$ positivity) was reported in $26 \%$ of patients, and metabolic abnormalities were present in 17 (7\%) subjects as diabetes mellitus, in $101(43.2 \%)$ as dyslipidemia and in $73(35.5 \%)$ as BMI $>25 \mathrm{~kg} / \mathrm{m}^{2}$. Aspartate aminotransferase, alanine aminotransferase, total bilirubin and platelet levels tended to be in the normal range. 


\subsection{Prevalence of Liver Fibrosis}

The median values of liver stiffness measurements by TE was $4.6 \mathrm{kPa}(\mathrm{IQR} 4.0-5.8 \mathrm{kPa})$ : F0-F1 stage was observed in 203 participants (86.8\%), F2 in 24 (10.2\%), F3 in 6 (2.6\%) and F4 in 1 case $(0.4 \%)$.

The median APRI score among 229 PLWH was 0.25 (IQR 0.18-0.31), with APRI $<0.5$ in $220(96.0 \%)$ individuals, $\geq 1.5$ in $1(0.4 \%)$ and $\geq 0.5$ but $<1.5$ in $8(3.6 \%)$.

The median FIB-4 score among 228 PLWH was 0.92 (IQR 0.71-1.20), with FIB-4<1.3 in $211(92.3 \%)$ patients, $\geq 2.67$ in $3(1.3 \%)$ and $\geq 1.3$ but $<2.67$ in $14(6.1 \%)$.

\subsection{Predictors of Liver Fibrosis Assessed by Transient Elastography}

In the multivariate linear regression model, after adjustment for potential confounders, a worse liver stiffness (measured by TE) was found to be associated with higher BMI (adjusted mean change +0.11 per 1 unit more; $95 \% \mathrm{CI}+0.00 /+0.19 ; p=0.01$ ), diabetes mellitus (adjusted mean change $+2.05 ; 95 \% \mathrm{CI}+0.77 /+3.32 ; p<0.01$ ), higher baseline HIV-1 RNA detectable (adjusted mean change $+1.07 ; 95 \% \mathrm{CI}+0.42 /+1.72 ; p<0.01$ ) and longer cumulative atazanavir exposure (adjusted mean change +0.14 per 1 year more; $95 \%$ CI + 0.05/ + 0.24; $p<0.01)($ Table 2$)$.

Table 2. Factors associated with liver stiffness (measured by TE) by linear regression models.

\begin{tabular}{|c|c|c|c|c|c|c|}
\hline \multicolumn{4}{|c|}{ Univariate Analysis } & \multicolumn{3}{|c|}{ Multivariate Analysis } \\
\hline Variable & $\begin{array}{l}\text { Mean } \\
\text { Change }\end{array}$ & $95 \%$ CI & $p$-Value & $\begin{array}{l}\text { Adjusted Mean } \\
\text { Change }\end{array}$ & $95 \%$ CI & $p$-Value \\
\hline Age, per 10 years increase & 0.40 & $0.10 / 0.41$ & $<0.01$ & 0.24 & $-0.09 / 0.56$ & 0.15 \\
\hline Male gender & 0.65 & $0.15 / 1.15$ & 0.01 & -0.81 & $-1.63 / 0.01$ & 0.05 \\
\hline BMI, per 1 unit more & 0.10 & $0.04 / 0.16$ & $<0.01$ & 0.11 & $0.00 / 0.19$ & 0.01 \\
\hline Diabetes mellitus & 1.60 & $0.71 / 2.49$ & $<0.01$ & 2.05 & $0.77 / 3.32$ & $<0.01$ \\
\hline $\begin{array}{c}\text { Time from HIV diagnosis, per } \\
1 \text { year more }\end{array}$ & 0.05 & $0.02 / 0.07$ & $<0.01$ & 0.01 & $-0.06 / 0.05$ & 0.96 \\
\hline Nadir CD4, per 100 cell $/ \mu \mathrm{L}$ increase & -0.26 & $-0.49 / 0.04$ & 0.02 & -0.13 & $-0.35 / 0.08$ & 0.21 \\
\hline Baseline CD4/CD8 & -0.38 & $-0.76 / 0.01$ & 0.05 & -0.30 & $-0.79 / 0.18$ & 0.22 \\
\hline Detectable baseline HIV-1 RNA & 1.27 & $0.77 / 1.77$ & $<0.01$ & 1.07 & $0.42 / 1.72$ & $<0.01$ \\
\hline $\begin{array}{c}\text { Cumulative AZT exposure, per } \\
1 \text { year more }\end{array}$ & 0.06 & $0.01 / 0.16$ & 0.04 & -0.04 & $-0.13 / 0.06$ & 0.42 \\
\hline $\begin{array}{c}\text { Cumulative ATV exposure, per } \\
1 \text { year more }\end{array}$ & 0.08 & $0.01 / 0.16$ & 0.02 & 0.14 & $0.05 / 0.24$ & $<0.01$ \\
\hline
\end{tabular}

Legend: ATV, atazanavir; AZT, azidothymidine; BMI, body mass index.

In the multivariate logistic regression model, after adjustment for potential confounders, liver fibrosis $\geq$ F2 (stiffness $\geq 6.65 \mathrm{kPa}$ ) was found to be significantly associated with detectable HIV-1 RNA (vs. undetectable aOR +3.51; 95\% CI + 1.47/ + 8.38; $p<0.01$ ) and longer cumulative raltegravir exposure $(\mathrm{aOR}+1.23$ per 1 year more; $95 \% \mathrm{CI}+1.02 /+1.17 ; p=0.02)($ Table 3$)$.

Table 3. Predictors of liver fibrosis $\geq$ F2 (measured by TE) by logistic regression models.

\begin{tabular}{|c|c|c|c|c|c|c|}
\hline \multicolumn{4}{|c|}{ Univariate Analysis } & \multicolumn{3}{|c|}{ Multivariate Analysis } \\
\hline Variable & OR & $95 \%$ CI & $p$-Value & aOR & $95 \% \mathrm{CI}$ & $p$-Value \\
\hline Age, per 10 years increase & 1.94 & $1.32 / 2.84$ & $<0.01$ & 1.48 & $0.95 / 2.32$ & 0.08 \\
\hline Alcohol consumption * & 0.31 & $0.10 / 0.91$ & 0.03 & 0.35 & $0.11 / 1.17$ & 0.09 \\
\hline Years of HIV, per 1 year more & 1.09 & $1.04 / 1.14$ & $<0.01$ & 1.03 & $0.96 / 1.10$ & 0.38 \\
\hline Diabetes mellitus & 4.19 & $1.42 / 12.32$ & $<0.01$ & 2.19 & $0.59 / 8.10$ & 0.24 \\
\hline Detectable baseline HIV-1 RNA & 4.35 & $1.99 / 9.52$ & $<0.01$ & 3.51 & $1.47 / 8.38$ & $<0.01$ \\
\hline Cumulative AZT exposure, per 1 year more & 1.19 & $1.03 / 1.19$ & $<0.01$ & 1.07 & $0.97 / 1.19$ & 0.19 \\
\hline Cumulative ATV exposure, per 1 year more & 1.13 & $1.03 / 1.24$ & $<0.01$ & 1.10 & $0.99 / 1.24$ & 0.08 \\
\hline Cumulative RAL exposure, per 1 year more & 1.24 & $1.06 / 1.45$ & $<0.01$ & 1.23 & $1.02 / 1.17$ & 0.02 \\
\hline
\end{tabular}




\subsection{Predictors of Liver Fibrosis Assessed by APRI Score}

In the multivariate linear regression model, after adjustment for potential confounders, a higher APRI score was found to be associated with CDC C stage (adjusted mean change +0.06 ; $95 \% \mathrm{CI}+0.02 /+0.09 ; p<0.01$ ) and a longer exposure to tenofovir alafenamide (adjusted mean change +0.03 per 1 year more; $95 \% \mathrm{CI}+0.01 /+0.05 ; p<0.01$ ) (Table 4 ).

Table 4. Factors associated with APRI score by linear regression models.

\begin{tabular}{|c|c|c|c|c|c|c|}
\hline \multicolumn{4}{|c|}{ Univariate Analysis } & \multicolumn{3}{|c|}{ Multivariate Analysis } \\
\hline Variable & $\begin{array}{l}\text { Mean } \\
\text { Change }\end{array}$ & $95 \%$ CI & $p$-Value & $\begin{array}{c}\text { Adjusted } \\
\text { Mean Change }\end{array}$ & $95 \% \mathrm{CI}$ & $p$-Value \\
\hline CDC C stage & 0.08 & $0.05 / 0.11$ & $<0.01$ & 0.06 & $0.02 / 0.09$ & $<0.01$ \\
\hline $\mathrm{HbcAb}$ positivity & 0.07 & $0.00 / 0.13$ & 0.04 & 0.05 & $-0.01 / 0.11$ & 0.11 \\
\hline Diabetes mellitus & 0.16 & $0.05 / 0.27$ & $<0.01$ & 0.08 & $-0.02 / 0.18$ & 0.21 \\
\hline Cumulative D4T, per 1 year more & 0.02 & $0.01 / 0.04$ & $<0.01$ & 0.01 & $0.00 / 0.02$ & 0.14 \\
\hline Cumulative TAF, per 1 year more & 0.05 & $0.03 / 0.06$ & $<0.01$ & 0.03 & $0.01 / 0.05$ & $<0.01$ \\
\hline
\end{tabular}

Legend: D4T, stavudine; TAF, tenofovir alafenamide.

\subsection{Predictors of Liver Fibrosis Assessed by FIB-4 Score}

At multivariate linear regression analysis, after adjustment for potential confounders, we found association between higher FIB- 4 scores and $\mathrm{HbcAb}$ positivity (adjusted mean change $+0.17 ; 95 \% \mathrm{CI}+0.01 /+0.34 ; p=0.04)$ and longer cumulative exposure to TAF (adjusted mean change $+0.09 ; 95 \% \mathrm{CI}+0.03 /+0.14 ; p<0.01$ ) (Table 5).

Table 5. Predictors of liver fibrosis assessed by FIB-4 score by linear regression models.

\begin{tabular}{|c|c|c|c|c|c|c|}
\hline \multicolumn{4}{|c|}{ Univariate Analysis } & \multicolumn{3}{|c|}{ Multivariate Analysis } \\
\hline Variable & $\begin{array}{l}\text { Mean } \\
\text { Change }\end{array}$ & $95 \%$ CI & $p$-Value & $\begin{array}{c}\text { Adjusted } \\
\text { Mean Change }\end{array}$ & $95 \% \mathrm{CI}$ & $p$-Value \\
\hline $\begin{array}{c}\text { Time from HIV diagnosis, per } \\
1 \text { year more }\end{array}$ & 0.01 & $0.01 / 0.02$ & $<0.01$ & 0.00 & $-0.01 / 0.01$ & 0.78 \\
\hline $\mathrm{HbcAb}$ positivity & 0.20 & $0.04 / 0.37$ & 0.02 & 0.17 & $0.01 / 0.34$ & 0.04 \\
\hline Diabetes mellitus & 0.38 & $0.10 / 0.65$ & $<0.01$ & 0.21 & $-0.07 / 0.49$ & 0.15 \\
\hline Osteoporosis & 0.28 & $0.01 / 0.55$ & 0.04 & 0.12 & $-0.15 / 0.39$ & 0.40 \\
\hline $\begin{array}{l}\text { Cumulative AZT exposure, per } \\
1 \text { year more }\end{array}$ & 0.02 & $-0.00 / 0.03$ & 0.06 & -0.01 & $-0.03 / 0.01$ & 0.45 \\
\hline $\begin{array}{l}\text { Cumulative ddC exposure, per } \\
1 \text { year more }\end{array}$ & 0.13 & $0.01 / 0.25$ & 0.04 & 0.10 & $-0.02 / 0.22$ & 0.10 \\
\hline $\begin{array}{l}\text { Cumulative D4T exposure, per } \\
1 \text { year more }\end{array}$ & 0.05 & $0.01 / 0.09$ & $<0.01$ & 0.03 & $-0.02 / 0.07$ & 0.21 \\
\hline $\begin{array}{c}\text { Cumulative } 3 \mathrm{TC} \text { exposure, per } \\
1 \text { year more }\end{array}$ & 0.02 & $0.00 / 0.03$ & 0.02 & 0.01 & $-0.01 / 0.03$ & 0.23 \\
\hline
\end{tabular}

Legend: AZT, azidothymidine; ddC, zalcitabine; D4T, stavudine; TAF, tenofovir alafenamide.

\subsection{Correlation between Liver Stiffness Measured by TE and APRI or FIB-4 Scores}

A poor correlation between liver stiffness measured by TE and APRI score (Rho Spearman $0.006 ; p=0.93$ ) or FIB-4 score (Rho Spearman $0.05 ; p=0.41$ ) was observed by Spearman correlation test. However, the two models did not reach statistical significance (Figure 1a,b). 


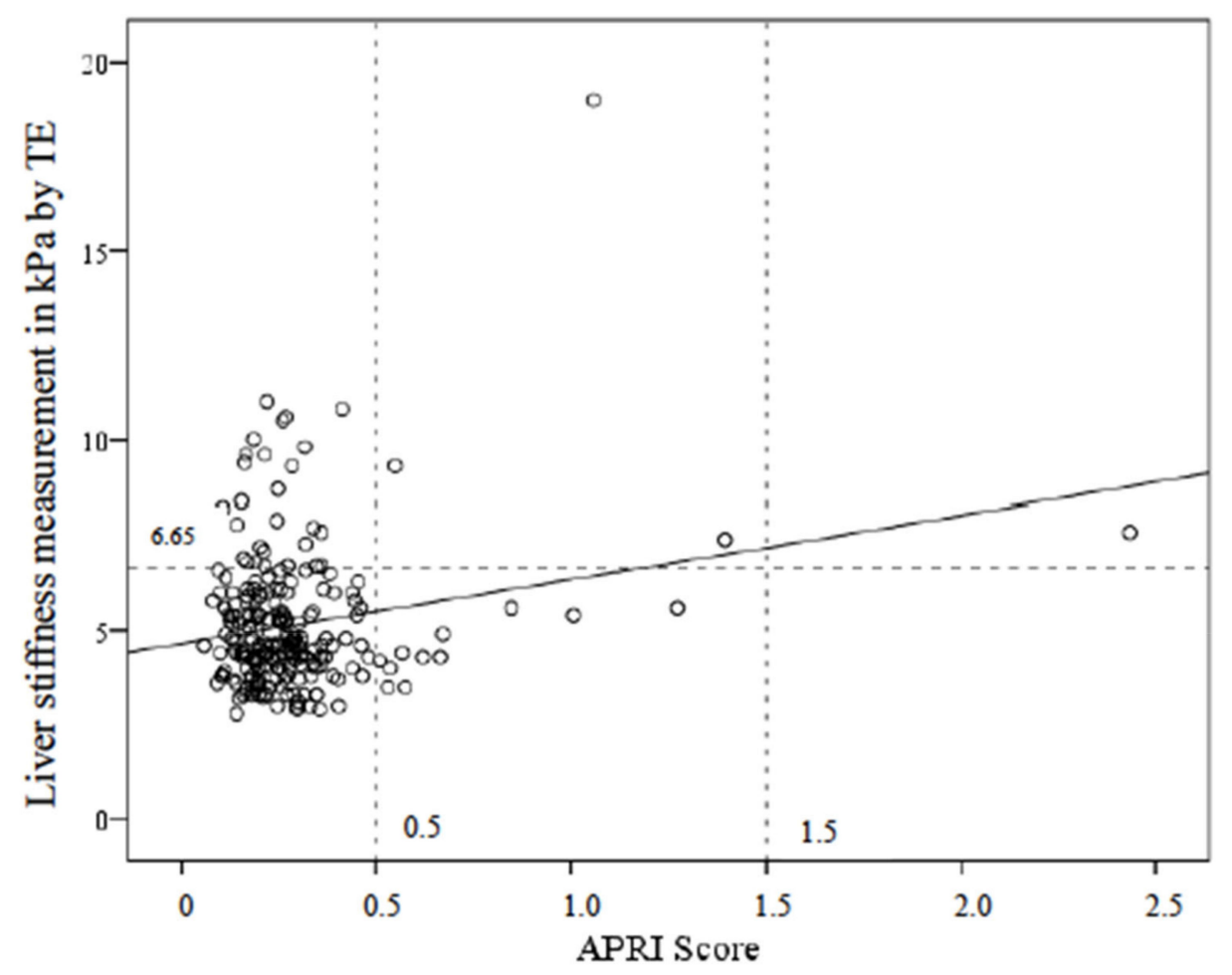

(a)

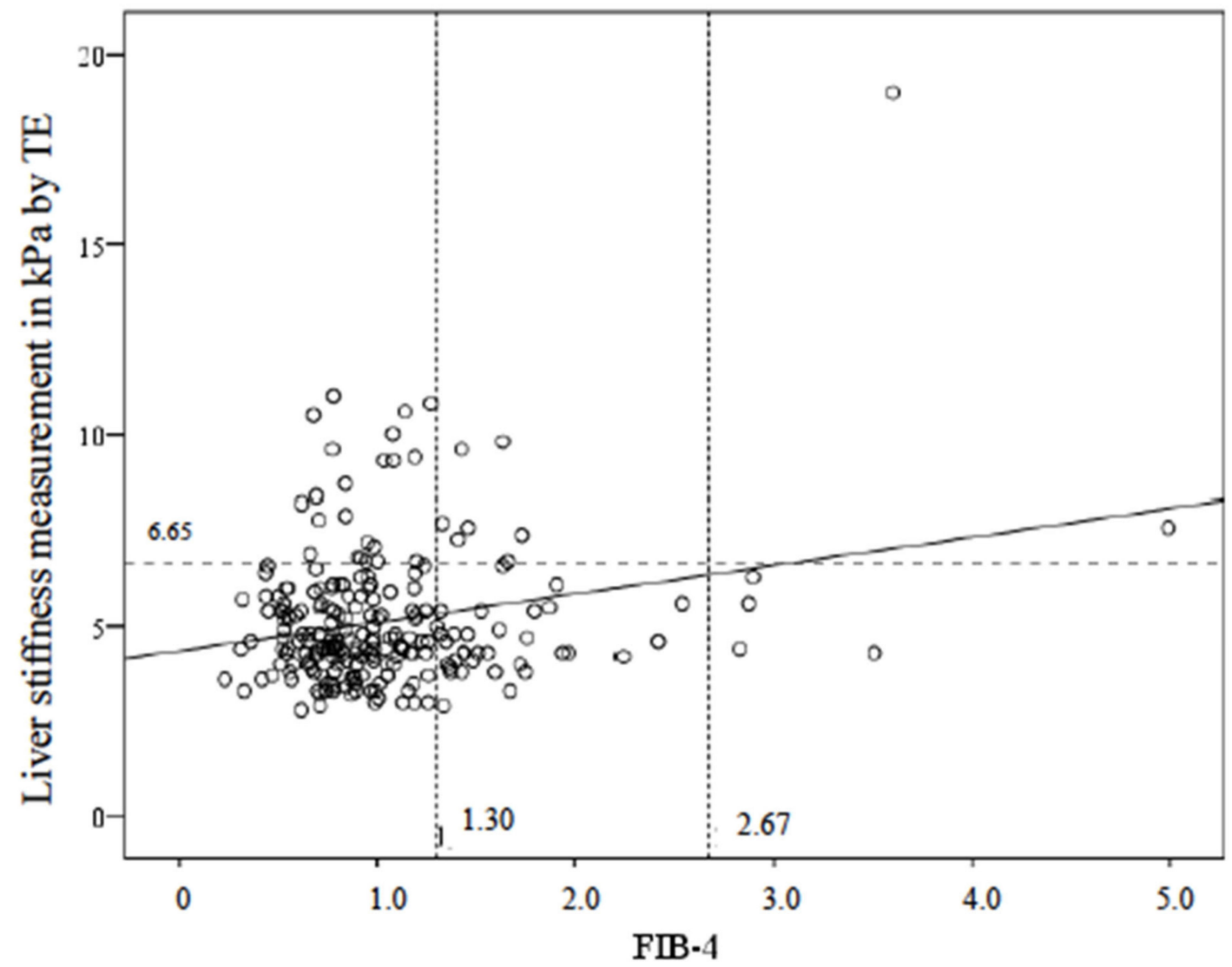

(b)

Figure 1. (a) Correlation between liver stiffness assessed by TE and APRI score. Rho Spearman 0.006; $p=0.93$. (b) Correlation between livers stiffness assessed by TE and FIB- 4 score. Rho Spearman 0.05; $p=0.41$. 


\subsection{Concordance between Significant Liver Stiffness by TE and APRI/FIB-4 Scores}

A significant liver fibrosis was defined as a stiffness $>6.65 \mathrm{kPa}$ by TE, an APRI score $>1.5$, and a FIB-4 score $>2.67$. Concordance between liver stiffness measured by TE and higher APRI and FIB4 scores in detecting significant liver fibrosis was studied using Kappa statistics. When comparing the concordance between TE results and APRI score, we observed a Cohen's K of $0.05(p=0.01)$, while Cohen's K was $0.10(p<0.01)$ when comparing TE results and FIB-4 score. Thus, we can infer that the concordance between TE results and APRI score or FIB-4 score in detecting significant liver fibrosis was poor.

\section{Discussion}

Liver disease is one of the major causes of morbidity and mortality in PLWH $[17,18]$. As far as liver fibrosis is concerned, available studies report that its prevalence in HIV-infected patients ranges from $1.4 \%$ to $63 \%$ according to different populations $[20,28,29,55,56]$. Several variables seem to contribute to liver fibrosis in HIV+ patients. Most liver events occur in PLWH co-infected with HBV-HCV viruses or in those with significant alcohol consumption. However, other factors could contribute to evolving liver fibrosis also in HIV infected subjects without viral hepatitis, but limited data are available on the prevalence and predictors of significant liver fibrosis in such population.

In our real-life population of HIV-infected people without Hepatitis Virus infection undergoing assessment of liver fibrosis at three Italian cohorts, the overall prevalence of liver stiffness $\geq F 2$ measured by transient elastography was $13.2 \%$. Importantly, liver biochemistry and platelet levels tended to be in the normal range in a wide proportion of study population. Since such a proportion is not negligible, this finding suggests that assessment of liver fibrosis should also be considered in HIV-infected people without Hepatitis Virus infection, especially in those with metabolic disorders, previous definitive AIDS conditions, past $\mathrm{HBV}$ infection, and longer exposure to antiretroviral drugs, particularly to NRTIs and PIs.

We also investigated predictors of liver fibrosis in our population. Similarly to previous studies, higher BMI and diabetes mellitus predicted severe liver fibrosis, suggesting an important role of metabolic disorders in progressive liver damage [22,25]. Globally, non-alcoholic fatty liver disease (NAFLD) is becoming the leading cause of chronic liver diseases $[57,58]$. PLWH have an increased risk of NAFLD due to chronic inflammation, persistent immune activation, and metabolic disorders [59]. According to a recent metaanalysis including five studies, the estimated prevalence of NAFLD among PLWH is around $35 \%$ and its liver-related prognosis is due to the amount of liver fibrosis accumulating over the years $[60,61]$.

Currently available antiretroviral drugs have dramatically changed the landscape of HIV infection, reducing mortality for any reason but increasing the impact of aging-related comorbidities. However, even if many controversies still exist, the potential impact of some antiretroviral drugs in mid- and long-term liver abnormalities is known, in particular due to first-generation NRTIs, such as AZT and PIs $[17,38]$. In our study, we observed an effect of longer cumulative atazanavir exposure on liver stiffness measurements by TE, according to previous literature data. Strikingly, a higher risk of increased liver fibrosis was associated to longer cumulative TAF exposure according to APRI and FIB-4 scores and to a longer cumulative RAL exposure among those with liver stiffness $\geq F 2$ at TE. These data are in line with previously published data, which showed that both drugs were associated with a significant weight gain after initiation of therapy and with development and progression of liver steatosis [62]. The accumulation of fat can cause liver inflammation, hepatic cell death and steatohepatitis, leading to faster progression of liver fibrosis over time in the absence of an effective intervention for harm reduction. Notably, in our cohort, almost all patients experienced previous NRTIs exposure and therefore TAF exposure could be a proxy for longer NRTI exposure over the years.

Although our study cohort exclusively included PLWH with HIV-1 RNA $<50$ copies $/ \mathrm{mL}$, liver fibrosis at TE was positively correlated with detectable baseline HIV-1 RNA, according 
to some previous experiences [63]. Despite multiple pathways of liver fibrosis development potentially existing, this interesting finding seems to confirm the association between HIV replication itself and liver fibrosis [64], probably related to an increased hepatic inflammation and fibrogenesis exacerbated by the virus.

Confirming previous findings, we observed an association between higher liver fibrosis predicted by APRI score and CDC C stage, underlining an effect of advanced immune system impairment at presentation $[39,63]$.

Finally, a higher FIB-4 score was associated with $\mathrm{HbcAb}$ positivity in our cohort enrolling HBsAg-negative HIV-infected people. Although $\mathrm{HBcAb}$ contribution in liver damage in HIV/HCV-infected individuals is well known, recently, other cohort studies seemed to exclude its association with advanced liver fibrosis in HIV infection without $\mathrm{HCV}$ [65-67]. Generally, HBcAb is considered the sign of previous HBV infection; however, it could be the marker of occult B infection (OBI), a clinical condition defined by the persistence of intrahepatic cccHBV-DNA. The risk of HBV-DNA replication/reactivation in OBI strongly supports the need of a careful monitoring for sign of past HBV infection [68].

In clinical practice, non-invasive methods are widely used to estimate of liver fibrosis. The non-invasive methods could identify PLWH at higher risk of severe liver injury, and liver fibrosis stratification may help to determine those who may benefit from lifestyle changes, including healthy diet, weight loss, physical exercise and metabolic disorder control, and potential pharmacologic interventions $[17,18,20]$. Non-invasive assessment of liver fibrosis can be performed (i) by biological approaches, quantifying serum biomarkers, with FIB-4 and APRI being the most used scores, or (ii) by a physical approach, measuring liver stiffness by TE. However, only a few non-invasive methods are validated in the specific setting of HIV mono-infection, and most data are available in adults with elevated aminotransferases on antiretroviral therapy [69].

Interestingly, in our population, mainly constituted by HIV-infected patients without hepatitis virus infection with normal aminotransferase levels, the different investigated non-invasive methods (transient elastography, FIB-4, and APRI) were discordant to predict liver fibrosis in this setting.

According to previous studies, a poor concordance between serum fibrosis biomarkers and TE results in detecting severe liver fibrosis in the specific setting of HIV monoinfection [70]. FIB-4 index was deeply influenced by age, whereas TE and APRI score were not. TE had the advantages over FIB-4 index and APRI score to be associated with portal hypertension and to be more accurate to detect advanced fibrosis in people affected by non-alcoholic fatty liver disease [71].

The strengths of the study are the large population recruited from three distinct clinical units in northern and central Italy and the use of easily accessible and validated non-invasive instrumental and labs tool to investigate liver fibrosis.

The main limitations include the inter-operator and instrument variability for transient elastography liver stiffness measurement and the lack of histological data to compare noninvasive methods results. Liver biopsy is considered the gold standard for the diagnosis of liver fibrosis [72]. However, this invasive procedure is only suitable for a selected group of people because of the risk of complications.

Indeed, given the lack of data regarding waist circumference to characterize participants phenotype, BMI was used to categorize normal and overweight/obese people, even if the potential underestimation of obesity by using only BMI in people with abnormal fat distribution is known (high visceral adiposity and/or low muscle mass).

\section{Conclusions}

In virologically suppressed HIV-1-infected people without viral hepatitis, we observed a significant liver fibrosis in a non-negligible proportion of subjects $(13.2 \%)$. Besides classic metabolic factors, some HIV-related variables (detectable HIV-RNA, exposure to certain antiretroviral drugs, previous AIDS events) were associated with an increased risk of significant fibrosis, suggesting that this population could be at increased risk of 
liver disease. Indeed, early detection of liver fibrosis is extremely important due to its independent risk of progression to severe liver damage, especially in PLWH with metabolic disorders, advanced HIV presentation and longer antiretroviral drug exposure.

Our findings also demonstrated that the different investigated non-invasive methods (transient elastography, FIB-4, and APRI) were poorly concordant to predict severe liver fibrosis in this setting. As a consequence, the best method for the estimation of liver fibrosis in this setting remains to be determined. A larger cohort, including more people with severe liver fibrosis, could offer the opportunity to explore different cut-off to improve sensibility and sensitivity of investigated methods.

Further longitudinal studies are needed because PLWH need a better understanding of liver disease beyond viral hepatitis coinfection.

Author Contributions: Conceptualization, B.R. and M.F.; methodology, B.R. and M.F.; formal analysis, A.E. and V.B.; investigation, V.B., G.Z., M.C., M.d., D.M., L.M., F.M., M.C.M., C.B., T.C.P., P.V., R.B., M.S. and M.P.; data curation, V.B.; writing-original draft preparation, B.R. and V.B.; writing-review and editing, B.R. and M.F. All authors have read and agreed to the published version of the manuscript.

Funding: This research received no external funding.

Institutional Review Board Statement: The study was conducted according to guidelines of the Declaration of Helsinki, and approved by Comitato Etico Regionale per la Sperimentazione Clinica della Regione Toscana, CEAVSE (protocol code 1237, date of approval 21 July 2014).

Informed Consent Statement: Not applicable.

Data Availability Statement: Not applicable.

Conflicts of Interest: B.R. received speakers' honoraria and support for travel to meetings from Gilead Sciences, Janssen-Cilag, Merck Sharp and Dohme (MSD), ViiV Healthcare, and Menarini, as well as fees for attending advisory boards from ViiV Healthcare, Janssen-Cilag, Merck Sharp and Dohme (MSD), Gilead Sciences, and Bristol Myers Squibb (BMS). F.M. received support for travel to meetings from Angelini; she is principal investigator in a sponsor study by TLS (Toscana Life Science) and by GSK Vaccine SRL, and she is the contact person for a service contract between GSK Vaccine SRL and Department of Medical Biotechnologies, University of Siena, without receiving any personal remuneration. M.F. received speakers' honoraria, support for travel to meetings, and/or fees for attending advisory boards from Bristol Myers Squibb (BMS), Gilead, Janssen-Cilag, Merck Sharp and Dohme (MSD), and ViiV Healthcare.

\section{References}

1. UNAIDS. Global HIV \& AIDS Statistics-2020 Fact Sheet. Available online: https://www.unaids.org/en/resources/fact-sheet (accessed on 17 October 2021).

2. Antiretroviral Therapy Cohort Collaboration. Life expectancy of individuals on combination antiretroviral therapy in high-income countries: A collaborative analysis of 14 cohort studies. Lancet 2008, 372, 293-299. [CrossRef]

3. Joshi, D.; O'Grady, J.; Dieterich, D.; Gazzard, B.; Agarwal, K. Increasing burden of liver disease in patients with HIV infection. Lancet 2011, 377, 1198-1209. [CrossRef]

4. Smith, C.J.; Ryom, L.; Weber, R.; Morlat, P.; Pradier, C.; Reiss, P.; Kowalska, J.D.; de Wit, S.; Law, M.; el Sadr, W.; et al. Trends in underlying causes of death in people with HIV from 1999 to 2011 (D:A:D): A multicohort collaboration. Lancet 2014, 384, 241-248. [CrossRef]

5. Alejos, B.; Hernando, V.; López-Aldeguer, J.; Segura, F.; Oteo, J.O.; Rubio, R.; Sanvisens, A.; Sobrino, p.; Del Amo, J.; Cohort Coris. Overall and cause-specific mortality in HIV-positive subjects compared to the general population. J. Int. AIDS Soc. 2014, $17,19711$. [CrossRef]

6. Weber, R.; Sabin, C.A.; Friis-Møller, N.; Reiss, P.; El-Sadr, W.M.; Kirk, O.; Dabis, M.; Law, M.G.; Pradier, C.; De Wit, S.; et al. Liver-related deaths in persons infected with the human immunodeficiency virus: The D:A:D study. Arch. Intern. Med. 2006, 166, 1632-1641. [CrossRef]

7. Eyawo, O.; Franco-Villalobos, C.; Hull, M.W.; Nohpal, A.; Samji, H.; Sereda, P.; Lima, V.D.; Shoveller, J.; Moore, D.; Montaner, J.S.G.; et al. Changes in mortality rates and causes of death in a population-based cohort of persons living with and without HIV from 1996 to 2012. BMC Infect. Dis. 2017, 17, 174. [CrossRef] 
8. Croxford, S.; Kitching, A.; Desai, S.; Kall, M.; Edelstein, M.; Skingsley, A.; Burns, F.; Copas, A.; Brown, A.E.; Sullivan, K.A.; et al. Mortality and causes of death in people diagnosed with HIV in the era of highly active antiretroviral therapy compared with the general population: An analysis of a national observational cohort. Lancet Public Health 2017, 2, e35-e46. [CrossRef]

9. Ingle, S.M.; May, M.T.; Gill, M.J.; Mugavero, M.J.; Lewden, C.; Abgrall, S.; Fätkenheuer, G.; Reiss, P.; Saag, M.S.; Manzardo, C.; et al. Impact of risk factors for specific causes of death in the first and subsequent years of antiretroviral therapy among HIV-infected patients. Clin. Infect. Dis. 2014, 59, 287-297. [CrossRef] [PubMed]

10. Sellier, P.; Hamet, G.; Brun, A.; Ponscarme, D.; De Castro, N.; Alexandre, G.; Rozenbaum, W.; Molina, J.M.; Abgrall, S.; COREVIH Ile-de-France-Est research group. Mortality of People Living with HIV in Paris Area from 2011 to 2015. AIDS Res. Hum. Retrovir 2020, 36, 373-380. [CrossRef]

11. Soriano, V.; Barreiro, P.; Sherman, K.E. The changing epidemiology of liver disease in HIV patients. AIDS Rev. 2013, 15, 25-31.

12. Kapoor, N.; Audsley, J.; Rupali, P.; Sasadeusz, J.; Paul, T.V.; Thomas, N.; Lewin, S.R. A gathering storm: HIV infection and non-alcoholic fatty liver disease in low and middle-income countries. Aids 2019, 33, 1105-1115. [CrossRef]

13. Macías, J.; Pineda, J.A.; Real, M.L. Non-Alcoholic Fatty Liver Disease in HIV Infection. AIDS Rev. 2017, 19, 35-46.

14. Rockstroh, J.K. Non-Alcoholic Fatty Liver Disease (NAFLD) and Non-Alcoholic Steatohepatitis (NASH) in HIV. Curr. HIV/AIDS Rep. 2017, 14, 47-53. [CrossRef]

15. Squillace, N.; Soria, A.; Bozzi, G.; Gori, A.; Bandera, A. Non-alcoholic fatty liver disease and steatohepatitis in people living with HIV. Expert Rev. Gastroenterol. Hepatol. 2019, 13, 643-650. [CrossRef] [PubMed]

16. Cervo, A.; Milic, J.; Mazzola, G.; Schepis, F.; Petta, S.; Krahn, T.; Lebouche, B.; Deschenes, M.; Cascio, A.; Guaraldi, G.; et al. Prevalence, Predictors, and Severity of Lean Nonalcoholic Fatty Liver Disease in Patients Living With Human Immunodeficiency Virus. Clin. Infect. Dis 2020, 71, e694-e701. [CrossRef]

17. Bakasis, A.-D.; Androutsakos, T. Liver Fibrosis during Antiretroviral Treatment in HIV-Infected Individuals. Truth or Tale? Cells 2021, 10, 1212. [CrossRef] [PubMed]

18. Kaspar, M.B.; Sterling, R.K. Mechanisms of liver disease in patients infected with HIV. BMJ Open Gastroenterol. 2017,4 , e000166. [CrossRef] [PubMed]

19. Wekesa, C.; Kirk, G.D.; Aizire, J.; Benson, E.M.; Karabarinde, A.; Parkes-ratanshi, R.; Ocama, P. Prevalence and Factors Associated with Liver Fibrosis Among Adult HIV-Infected Patients Attending Urban and Rural Care Clinics in Uganda. Open Forum Infect. Dis. 2020, 7, ofaa483. [CrossRef]

20. Androutsakos, T.; Schina, M.; Pouliakis, A.; Kontos, A.; Sipsas, N.; Hatzis, G. Causative factors of liver fibrosis in HIV-infected patients. A single center study. BMC Gastroenterol. 2020, 20, 91. [CrossRef] [PubMed]

21. Bilal, U.; Lau, B.; Lazo, M.; McCaul, M.E.; Hutton, H.E.; Sulkowski, M.S.; Moore, R.D.; Chander, G. Interaction Between Alcohol Consumption Patterns, Antiretroviral Therapy Type, and Liver Fibrosis in Persons Living with HIV. AIDS Patient Care STDS 2016, 30, 200-207. [CrossRef]

22. Castellares, C.; Barreiro, P.; Martin-Carbonero, L.; Labarga, P.; Vispo, M.E.; Casado, R.; Galindo, L.; Garcìa-Gascò, P.; Garcia-Samaniego, J.; Soriano, V. Liver cirrhosis in HIV-infected patients: Prevalence, aetiology and clinical outcome. J. Viral. Hepat. 2008, 15, 165-172. [CrossRef]

23. Ferguson, T.F.; Rosen, E.; Carr, R.; Brashear, M.; Simon, L.; Theall, K.P.; Ronis, M.J.; Welsh, D.A.; Molina, P.E. Associations of Liver Disease with Alcohol Use among People Living with HIV and the Role of Hepatitis C: The New Orleans Alcohol Use in HIV Study. Alcohol Alcohol. 2020, 55, 28-36. [CrossRef]

24. Jaquet, A.; Wandeler, G.; Nouaman, M.; Ekouevi, D.K.; Tine, J.; Patassi, A.; Coffie, P.A.; Tanon, A.; Seydi, M.; Attia, A.; et al Alcohol use, viral hepatitis and liver fibrosis among HIV-positive persons in West Africa: A cross-sectional study. J. Int. AIDS Soc. 2017, 19, 21424. [CrossRef]

25. Kirk, G.D.; Mehta, S.H.; Astemborski, J.; Galai, N.; Washington, J.; Higgins, Y.; Balagopal, A.; Thomas, D.L. HIV, age, and the severity of hepatitis C virus-related liver disease: A cohort study. Ann. Intern. Med. 2013, 158, 658-666. [CrossRef]

26. Martín-Carbonero, L.; Benhamou, Y.; Puoti, M.; Berenguer, J.; Mallolas, J.; Quereda, C.; Arizcorreta, A.; Gonzalez, A.; Rockstroh, J.; Asensi, V.; et al. Incidence and predictors of severe liver fibrosis in human immunodeficiency virus-infected patients with chronic hepatitis C: A European collaborative study. Clin. Infect. Dis. 2004, 38, 128-133. [CrossRef]

27. Fuster, D.; Planas, R.; Muga, R.; Ballesteros, A.L.; Santos, J.; Tor, J.; Sirera, G.; Guardiola, H.; Salas, A.; Cabré, E.; et al. Advanced liver fibrosis in HIV/HCV-coinfected patients on antiretroviral therapy. AIDS Res. Hum. Retrovir. 2004, 20, 1293-1297. [CrossRef]

28. Kooij, K.W.; Wit, F.W.N.M.; van Zoest, R.A.; Schouten, J.; Kootstra, N.A.; van Vugt, M.; Prins, M.; Reiss, P.; van der Valk, M.; AGEhIV Cohort Study Group. Liver fibrosis in HIV-infected individuals on long-term antiretroviral therapy: Associated with immune activation, immunodeficiency and prior use of didanosine. Aids 2016, 30, 1771-1780. [CrossRef]

29. Wei, Q.; Lin, H.; Ding, Y.; Liu, X.; Wu, Q.; Shen, W.; Gao, M.; He, N. Liver fibrosis after antiretroviral therapy in a longitudinal cohort of sexually infected HIV patients in eastern China. Biosci. Trends 2017, 11, 274-281. [CrossRef]

30. Wong, J.K.; Yukl, S.A. Tissue reservoirs of HIV. Curr. Opin. HIV AIDS 2016, 11, 362-370. [CrossRef]

31. Ganesan, M.; Poluektova, L.Y.; Kharbanda, K.K.; Osna, N.A. Liver as a target of human immunodeficiency virus infection. World J. Gastroenterol. 2018, 24, 4728-4737. [CrossRef] 
32. Tuyama, A.C.; Hong, F.; Saiman, Y.; Wang, C.; Ozkok, D.; Mosoian, A.; Chen, P.; Chen, B.K.; Klotman, M.E.; Bansal, M.B. Human immunodeficiency virus (HIV)-1 infects human hepatic stellate cells and promotes collagen I and monocyte chemoattractant protein-1 expression: Implications for the pathogenesis of HIV/hepatitis C virus-induced liver fibrosis. Hepatology 2010, 52, 612-622. [CrossRef]

33. Begriche, K.; Massart, J.; Robin, M.A.; Bonnet, F.; Fromenty, B. Mitochondrial adaptations and dysfunctions in nonalcoholic fatty liver disease. Hepatology 2013, 58, 1497-1507. [CrossRef] [PubMed]

34. Zhang, L.; Mosoian, A.; Schwartz, M.E.; Florman, S.S.; Gunasekaran, G.; Schiano, T.; Fiel, M.I.; Jiang, W.; Shen, Q.; Branch, A.D.; et al. HIV infection modulates IL-1_ response to LPS stimulation through a TLR4-NLRP3 pathway in human liver macrophages. J. Leukoc. Biol. 2019, 105, 783-795. [CrossRef]

35. Balagopal, A.; Philp, F.H.; Astemborski, J.; Block, T.M.; Mehta, A.; Long, R.; Kirk, G.D.; Mehta, S.H.; Cox, A.L.; Thomas, D.L.; et al Human immunodeficiency virus-related microbial translocation and progression of hepatitis C. Gastroenterology 2008, 135, 226-233. [CrossRef]

36. Dharan, N.J.; Neuhaus, J.; Rockstroh, J.K.; Peters, L.; Gordin, F.; Arenas-Pinto, A.; Emerson, C.; Marks, K.; Hidalgo, J.; SarmentoCastro, R.; et al. Benefit of Early versus Deferred Antiretroviral Therapy on Progression of Liver Fibrosis among People with HIV in the START Randomized Trial. Hepatology 2019, 69, 1135-1150. [CrossRef]

37. Cihlar, T.; Ray, A.S. Nucleoside and nucleotide HIV reverse transcriptase inhibitors: 25 years after zidovudine. Antivir. Res. 2010, 85, 39-58. [CrossRef]

38. Margolis, A.M.; Heverling, H.; Pham, P.A.; Stolbach, A. A review of the toxicity of HIV medications. J. Med. Toxicol. 2014, 10, 26-39. [CrossRef]

39. Focà, E.; Fabbiani, M.; Prosperi, M.; Quiros Roldan, E.; Castelli, F.; Maggiolo, F.; Di Filippo, E.; Di Giambenedetto, S.; Gagliardini, R.; Saracino, A.; et al. Liver fibrosis progression and clinical outcomes are intertwined: Role of CD4+ T-cell count and NRTI exposure from a large cohort of HIV/HCV-coinfected patients with detectable HCV-RNA: A MASTER cohort study. Medicine 2016, 95, e4091. [CrossRef]

40. Kolakowska, A.; Maresca, A.F.; Collins, I.J.; Cailhol, J. Update on Adverse Effects of HIV Integrase Inhibitors. Curr. Treat. Options Infect. Dis. 2019, 11, 372-387. [CrossRef]

41. Macías, J.; Mancebo, M.; Merino, D.; Téllez, F.; Montes-Ramìrez, M.L.; Pulido, F.; Rivero-Jùarez, A.; Raffo, M.; Pérez-Pérez, M.; Merchante, N.; et al. Changes in Liver Steatosis After Switching From Efavirenz to Raltegravir Among Human Immunodeficiency Virus-Infected Patients With Nonalcoholic Fatty Liver Disease. Clin. Infect. Dis. 2017, 65, 1012-1019. [CrossRef]

42. Palmon, R.; Koo, B.C.; Shoultz, D.A.; Dieterich, D.T. Lack of hepatotoxicity associated with nonnucleoside reverse transcriptase inhibitors. J. Acquir. Immune Defic. Syndr. 2002, 29, 340-345. [CrossRef]

43. Martí-Rodrigo, A.; Alegre, F.; Moragrega, A.B.; Garcìa-Garcìa, F.; Martì-Rodrigo, F.P.; Fernàndez-Iglesias, A.; Gracia-Sancho, J.; Apostolova, N.; Esplugues, J.V.; Blas-Garcia, A. Rilpivirine attenuates liver fibrosis through selective STAT1-mediated apoptosis in hepatic stellate cells. Gut 2020, 69, 920-932. [CrossRef] [PubMed]

44. Loko, M.A.; Bani-Sadr, F.; Winnock, M.; Lacombe, K.; Carrieri, P.; Neau, D.; Morlat, P.; Serfaty, L.; Dabis, F.; Salmon, D.; et al. Impact of HAART exposure and associated lipodystrophy on advanced liver fibrosis in HIV/HCV-coinfected patients. J. Viral Hepat. 2011, 18, e307-e314. [CrossRef]

45. Flint, O.P.; Noor, M.A.; Hruz, P.W.; Hylemon, P.B.; Yarasheski, K.; Kotler, D.P.; Parker, R.A.; Bellamine, A. The role of protease inhibitors in the pathogenesis of HIV-associated lipodystrophy: Cellular mechanisms and clinical implications. Toxicol. Pathol. 2009, 37, 65-77. [CrossRef]

46. Macías, J.; Mira, J.A.; Lòpez-Cortès, L.F.; Santos, I.; Giròn-Gonzàlez, J.A.; Gonzàlez-Serrano, M.; Merino, D.; Hernàndez-Quero, J.; Rivero, A.; Merchante, N.; et al. Antiretroviral therapy based on protease inhibitors as a protective factor against liver fibrosis progression in patients with chronic hepatitis C. Antivir. Ther. 2006, 11, 839-846. [PubMed]

47. Castera, L. Transient elastography and other noninvasive tests to assess hepatic fibrosis in patients with viral hepatitis. J. Viral Hepat. 2009, 16, 300-314. [CrossRef]

48. Castéra, L.; Vergniol, J.; Foucher, J.; Le Bail, B.; Chanteloup, E.; Haaser, M.; Darriet, M.; Couzigou, P.; De Lédinghen, V. Prospective comparison of transient elastography, Fibrotest, APRI, and liver biopsy for the assessment of fibrosis in chronic hepatitis C. Gastroenterology 2005, 128, 343. [CrossRef]

49. Singal, A.G.; Thomassen, L.V.; Gretch, D.R.; Shuhart, M.C. Use of the AST to platelet ratio index in HCV/HIV co-infected patients. Aliment. Pharmacol. Ther. 2011, 33, 566. [CrossRef] [PubMed]

50. Lieber, C.S.; Weiss, D.G.; Morgan, T.R.; Paronetto, F. Aspartate aminotransferase to platelet ratio index in patients with alcoholic liver fibrosis. Am. J. Gastroenterol. 2006, 101, 1500. [CrossRef]

51. Vallet-Pichard, A.; Mallet, V.; Nalpas, B.; Verkarre, V.; Nalpas, A.; Dhallluin-Venier, V.; Fontaine, H.; Pol, S. FIB-4: An inexpensive and accurate marker of fibrosis in HCV infection. Comparison with liver biopsy and fibrotest. Hepatology 2007, 46, 32. [CrossRef]

52. Sterling, R.K.; Lissen, E.; Clumeck, N.; Sola, R.; Correa, M.C.; Montaner, J.; Sulkowski, M.S.; Torriani, F.J.; Dieterich, D.T.; Thomas, D.L.; et al. Development of a simple noninvasive index to predict significant fibrosis in patients with HIV/HCV coinfection. Hepatology 2006, 43, 1317. [CrossRef] [PubMed]

53. Petta, S.; Vanni, E.; Bugianesi, E.; Di Marco, V.; Cammà, C.; Cabibi, D.; Mezzabotta, L.; Carxì, A. The combination of liver stiffness measurement and NAFLD fibrosis score improves the non-invasive diagnostic accuracy for severe liver fibrosis in patients with non-alcoholic fatty liver disease. Liver Int. 2015, 35, 1566-1573. [CrossRef] 
54. Eddowes, P.J.; Sasso, M.; Allison, M.; Tsochatzis, E.; Anstee, Q.M.; Sheridan, D.; Guha, I.N.; Cobbold, J.F.; Deeks, J.J.; Paradis, V.; et al. Accuracy of FibroScan Controlled Attenuation Parameter and Liver Stiffness Measurement in Assessing Steatosis and Fibrosis in Patients With Non-alcoholic Fatty Liver Disease. Gastroenterology 2019, 156, 1717-1730. [CrossRef] [PubMed]

55. Vermehren, J.; Vermehren, A.; Mueller, A.; Carlebach, A.; Lutz, T.; Gute, P.; Knecht, G.; Sarrazin, C.; Friedrich-Rust, M.; Forestier, N.; et al. Assessment of liver fibrosis and associated risk factors in HIV-infected individuals using transient elastography and serum biomarkers. BMC Gastroenterol. 2012, 12, 27. [CrossRef]

56. Ingiliz, P.; Valantin, M.A.; Duviver, C.; Medja, F.; Dominguez, S.; Charlotte, F.; Tubiana, R.; Poynard, T.; Katlama, C.; Lombés, A.; et al. Liver damage underlying unexplained transaminase elevation in human immunodeficiency virus-1 monoinfected patients on antiretroviral therapy. Hepatology 2009, 49, 436-442. [CrossRef] [PubMed]

57. Rinella, M.; Charlton, M. The globalization of non-alcoholic fatty liver disease: Prevalence and impact on world health. Hepatology 2016, 64, 19-22. [CrossRef]

58. Chalasani, N.; Younossi, Z.; Lavine, J.E.; Charlton, M.; Cusi, K.; Rinella, M.; Harrison, S.A.; Brunt, E.M.; Sanyal, A.J. The diagnosis and management of non-alcoholic fatty liver disease: Practice guidance from the American Association for the Study of Liver Diseases. Hepatology 2017, 67, 328-357. [CrossRef]

59. Lemoine, M.; Serfaty, L.; Capeau, J. From non-alcoholic fatty liver to non-alcoholic steatohepatitis and cirrhosis in HIV-infected patients: Diagnosis and management. Curr. Opin. Infect. Dis. 2012, 25, 10-16. [CrossRef] [PubMed]

60. Maurice, J.B.; Patel, A.; Scott, A.J.; Patel, K.; Thursz, M.; Lemoine, M. Prevalence and risk factors of non-alcoholic fatty liver disease in HIV-monoinfection. Aids 2017, 31, 1621-1632. [CrossRef]

61. Angulo, P. Long-term mortality in non-alcoholic fatty liver disease: Is liver histology of any prognostic significance? Hepatology 2010, 51, 373-375. [CrossRef]

62. Bischoff, J.; Gu, W.; Schwarze-Zander, C.; Boesecke, C.; Wasmuth, J.C.; van Bremen, K.; Dold, L.; Rockstroh, J.K.; Trebicka, J. Stratifying the risk of NAFLD in patients with HIV under combination antiretroviral therapy (cART). EClinicalMedicine 2021, 40, 101116. [CrossRef] [PubMed]

63. Blackard, J.T.; Welge, J.A.; Taylor, L.E.; Mayer, K.H.; Klein, R.S.; Celentano, D.D.; Jamieson, D.J.; Gardner, L.; Sherman, K.E. HIV mono-infection is associated with FIB-4-A noninvasive index of liver fibrosis in women. Clin. Infect. Dis. 2011, 52, 674-680. [CrossRef]

64. Perazzo, H.; Cardoso, S.W.; Yanavich, C.; Nunes, E.P.; Morata, M.; Gorni, N.; da Silva, P.S.; Cardoso, C.; Almeida, C.; Luz, P.; et al Predictive factors associated with liver fibrosis and steatosis by transient elastography in patients with HIV mono-infection under long-term combined antiretroviral therapy. J. Int. AIDS Soc. 2018, 21, e25201. [CrossRef]

65. Bonacini, M.; Louie, S.; Bzowej, N.; Wohl, A.R. Survival in patients with HIV infection and viral hepatitis B or C: A cohort study. Aids 2004, 18, 2039-2045. [CrossRef] [PubMed]

66. Bhattacharya, D.; Tseng, C.H.; Tate, J.P.; Lo Re, V.; Gilbert, C.L.; Butt, A.A.; Brown, S.T.; Lim, J.K.; Rodriguez-Barradas, M.C.; Rimland, D.; et al. Isolated hepatitis B core antibody is associated with advanced hepatic fibrosis in $\mathrm{HIV} / \mathrm{HCV}$ infection but not in HIV infection alone. J. Acquir. Immune Defic. Syndr. 2016, 72, e14-e17. [CrossRef]

67. Malagnino, V.; Cerva, C.; Cingolani, A.; Ceccherini-Silberstein, F.; Vergori, A.; Cuomo, G.; Perno, C.F.; Puoti, M.; d’Arminio Monforte, A.; Cozzi-Lepri, A.; et al. HBcAb Positivity Increases the Risk of Severe Hepatic Fibrosis Development in HIV/HCVPositive Subjects From the ICONA Italian Cohort of HIV-Infected Patients. Open Forum Infect. Dis. 2020, 8, ofaa566. [CrossRef]

68. Chang, J.J.; Mohtashemi, N.; Bhattacharya, D. Significance and management of isolated hepatitis B core antibody (anti-HBc) in HIV and HCV: Strategies in the DAA era. Curr. HIV/AIDS Rep. 2018, 15, 172-181. [CrossRef]

69. Morse, C.G.; McLaughlin, M.; Proschan, M.; Koh, C.; Kleiner, D.E.; Helelr, T.; Kovacs, J.A. Transient elastography for the detection of hepatic fibrosis in HIV-monoinfected adults with elevated aminotransferase on antiretroviral therapy. Aids 2015, 29, 2297-2302. [CrossRef]

70. Kirkegaard-Klitbo, D.M.; Bendtsen, F.; Lundgren, J.; Nielsen, S.D.; Benfield, T.; COCOMO study group. Poor concordance between liver stiffness and noninvasive fibrosis scores in HIV infection without viral hepatitis. Clin. Gastroenterol. Hepatol. 2019, 18, 3049-3050. [CrossRef]

71. Vuille-Lessard, E.; Rodrigues, S.E.; Berzigotti, A. Non invasive Detection of Clinically Significant Portal Hypertension in Compensated Advanced Chronic Liver Disease. Clin. Liver Dis. 2021, 25, 253-289. [CrossRef] [PubMed]

72. European Association for the Study of The Liver; European Association for the Study of Diabetes. EASL-EASD-EASO Clinical Practice Guidelines for the management of non-alcoholic fatty liver disease. J. Hepatol. 2016, 64, 1388-1402. [CrossRef] [PubMed] 